\author{
Малашенкова И.К. ${ }^{1,2}$, Огурцов Д.П.., ${ }^{1,}$ Крынский С.А. \\ Хайлов Н.А. ${ }^{1}$, Селезнева Н.Д. ${ }^{3}$, Федорова Я.Б. ${ }^{3}$, Пономарева Е.В. ${ }^{3}$, \\ Колыхалов И.В. ${ }^{3}$, Гаврилова С.И. ${ }^{3}$, Дидковский Н.А. ${ }^{2}$ \\ ${ }^{1}$ Национальный исследовательский центр «Курчатовский институт», Москва, Россия \\ ${ }^{2}$ ФГБУ «Федеральный научно-клинический центр физико-химической медицины ФМБА России», Москва, \\ Россия \\ ${ }^{3}$ ФГБНУ «Научный иентр психического здоровья», Москва, Россия
}

Резюме. Болезнь Альцгеймера (БА) - в настоящее время наиболее частая причина деменции. Значительная роль в патогенезе БА принадлежит активации механизмов врожденного иммунного ответа ЦНС и нейровоспалению. Существует гипотеза, что в развитии и поддержании воспалительной реакции на ранних стадиях БА могут иметь значение хронические инфекции. Целью настоящего исследования являлось изучение частоты выявления и уровня ДНК герпесвирусов, а также их возможной связи с уровнем основных цитокинов врожденного и адаптивного иммунного ответа и с клиническими показателями при БА у больных с ранним и поздним началом заболевания. В исследование вошли 30 больных БА на стадии умеренной деменции и 33 здоровых добровольца. Количественное определение ДНК герпесвирусов (CMV, EBV, HHV-6, HHV-7) в слюне и в крови проводили методом ПЦР с гибридизационно-флуоресцентной детекцией в режиме «реального времени». Уровень цитокинов и растворимого антагониста IL-1 $\beta$ (IL-1 ra) в крови определяли методом ИФА. Герпесвирусную инфекцию с повышенной вирусной нагрузкой определяли, учитывая предыдущие данные, полученные авторами, при наличии хотя бы одного из 2 критериев: 1) уровень ДНК вирусов EBV и/или HHV-6 более 10000 копий/мл в слюне; 2) наличие ДНК хотя бы одного из вирусов EBV, HHV-6, HHV-7 в крови. Выявлено, что при раннем начале достоверно чаще обнаруживался HHV-6 в слюне и крови, а при позднем - EBV в слюне. При раннем начале в подгруппе больных с повышенной вирусной нагрузкой было достоверно более выраженное повышение уровней ряда основных цитокинов: провоспалительных цитокинов IL-8 и IL-12p40p70, цитокина Th2-звена адаптивного иммунного отве-

\author{
Адрес для переписки: \\ Малашенкова Ирина Константиновна \\ Национальный исследовательский центр \\ «Курчатовский институт» \\ 123182, Россия, Москва, \\ пломадь Академика Курчатова, 1. \\ Тел.: 8(916) 935-73-09. \\ E-mail: malashenkova.irina@bk.ru
}

\section{Образец цитирования:}

И.К. Малашенкова, Д.П. Огурцов, С.А. Крынский, Н.А. Хайлов, Н.Д. Селезнева, Я.Б. Федорова,

Е.В. Пономарева, И.В. Колыхалов, С.И. Гаврилова,

Н.А. Дидковский «Герпесвирусные инфекции и клиникоиммунологические взаимодействия при болезни

Альцгеймера с ранним началом и болезни Альцгеймера с поздним началом» // Медицинская иммунология, 2021. T. 23, № 4. C. 805-812.

doi: 10.15789/1563-0625-HIA-2168

(С) Малашенкова И.К. и соавт., 2021

\author{
Address for correspondence: \\ Malashenkova Irina $K$. \\ National Research Center "Kurchatov Institute" \\ 123182, Russian Federation, Moscow, Acad. Kurchatov sq., 1. \\ Phone: 7 (916) 935-73-09. \\ E-mail: malashenkova.irina@bk.ru
}

For citation:

I.K. Malashenkova, D.P. Ogurtsov, S.A. Krynskiy, N.A. Khailov, N.D. Selezneva, Ya.B. Fedorova,

E.V. Ponomareva, I.V. Kolykhalov, S.I. Gavrilova,

N.A. Didkovsky "Herpesvirus infections and clinicalimmunologic interactions in patients with early-onset Alzheimer's disease and late-onset Alzheimer's disease”, Medical Immunology (Russia)/Meditsinskaya Immunologiya, 2021, Vol. 23, no. 4, pp. 805-812.

doi: $10.15789 / 1563-0625-H I A-2168$

DOI: $10.15789 / 1563-0625-H I A-2168$ 
та IL-4, цитокина адаптивного иммунного ответа IL-2, хотя уровень противовоспалительного белка IL-1ra был достоверно ниже, чем в контрольной группе. Учитывая отсутствие выраженного роста уровня основного цитокина Th1-звена адаптивного ответа IFN $\gamma$, эти изменения могут свидетельствовать о нарушении реакций противовирусной защиты, с активацией системного воспаления и Th2звена иммунитета. Также при раннем начале повышенная вирусная нагрузка была связана с более низкими баллами Бостонского теста называния, отражающего сохранность номинативной функции речи. Представленные результаты свидетельствуют, что при исследованиях механизмов БА и поиске прогностических маркеров болезни важным является учет неоднородности заболевания по генетическим факторам предрасположенности, факторам риска, особенностям иммунитета и клиническим данным, что необходимо для последующей разработки персонализированных подходов к профилактике и лечению БА.

\title{
HERPESVIRUS INFECTIONS AND CLINICAL-IMMUNOLOGIC INTERACTIONS IN PATIENTS WITH EARLY-ONSET ALZHEIMER'S DISEASE AND LATE-ONSET ALZHEIMER'S DISEASE
}

\author{
Malashenkova I.K. ${ }^{\text {a, }}$, Ogurtsov D.P., b, Krynskiy S.A. ${ }^{a}$, Khailov N.A. ${ }^{\text {, }}$, \\ Selezneva N.D. ${ }^{c}$, Fedorova Ya.B. ${ }^{c}$, Ponomareva E.V.c, Kolykhalov I.V. ${ }^{c}$, \\ Gavrilova S.I. , $^{\text {Didkovsky N.A. }}{ }^{\text {b }}$ \\ a National Research Center "Kurchatov Institute”, Moscow, Russian Federation \\ ${ }^{b}$ Federal Research and Clinical Center of Physical-Chemical Medicine, Federal Medical-Biological Agency of Russia, \\ Moscow, Russian Federation \\ ${ }^{c}$ Mental Health Research Center, Moscow, Russian Federation
}

\begin{abstract}
Alzheimer's disease (AD) is currently the most common cause of dementia. A significant role in the pathogenesis of $\mathrm{AD}$ belongs to the activation of the mechanisms of neuroinflammation. There is a hypothesis that chronic infections may play a role in the maintenance of the inflammatory response in AD. The aim of this work was to study the detection rate and DNA level of herpesviruses, as well as their possible relationship with the level of the key cytokines and with clinical parameters of AD in patients with early and late onset. 30 patients with $\mathrm{AD}$ and 33 healthy volunteers were enrolled. The quantitative determination of DNA of CMV, EBV, HHV-6, HHV-7 was carried out by PCR. The level of cytokines and soluble IL-1 $\beta$ antagonist (IL-1ra) in the blood was determined by ELISA. Herpesvirus infection with increased viral load was determined if at least one of the criteria was present: 1) DNA level of EBV and/or HHV-6 > 10,000 copies/ml in saliva; 2) presence of DNA of at least one of the EBV, HHV-6, HHV-7 viruses in the blood. In the subgroup of patients with early onset and increased viral load, there was a higher increase in the levels of a number of cytokines: proinflammatory IL-8 and IL-12, a Th2-cytokine IL-4, a cytokine of the adaptive immune response IL-2. However, the level of the anti-inflammatory protein IL-1ra was lower than in the controls. These changes may indicate a dysregulation of the antiviral response, with a predominance of activation of systemic inflammation and Th2-mediated reactions. Also, in early onset AD the increased viral load was associated with lower scores on Boston naming test. The results indicate that in studies of AD mechanisms and in the search for prognostic markers of the disease, it is important to take into account the heterogeneity of $\mathrm{AD}$ in terms of genetic predisposition factors, risk factors, immune parameters and clinical data. Such approach is necessary for the subsequent development of personalized approaches to the prevention and treatment of AD.
\end{abstract}

Keywords: Alzheimer's disease, aMCI, Boston naming test, EBV, HHV-6, HHV-7, IFN , MMSE 
This work was conducted as a part of the State Assignment of the National Research Center "Kurchatov Institute".

\section{Introduction}

Alzheimer's disease (AD) is currently the most common cause of dementia. According to the WHO, in 2017, about 47.5 million people suffered from $\mathrm{AD}$. This number is expected to triple over the next 35 years, making $\mathrm{AD}$ one of the most serious public health problems [1]. There are two forms of AD: early-onset Alzheimer's disease (EOAD) and lateonset $\mathrm{AD}$ (LOAD). EOAD accounts for less than $10 \%$ of cases of the disease; but often progresses rapidly, and has notorious social and economic importance [11]. Most cases of EOAD are genetically determined by dominant mutations in the genes of the amyloid precursor protein (APP) presenilin-1 (PS1) or presenilin-2 (PS2) [16]. With these mutations, there is an increased formation of amyloid-beta (A $\beta) 42$ in the central nervous system (CNS) and in other tissues of the body. $A \beta$ contributes to the pronounced manifestations of oxidative stress, having a toxic effect on mitochondria: it reduces the number of mitochondrial complexes I and IV, disrupting the functioning of the oxygen transport chain and oxidative phosphorylation [11]. LOAD accounts for up to $90 \%$ of cases of Alzheimer's disease and is a multifactorial disease that is often associated with the presence of the genetic polymorphism ApoE\&4, which contributes to disorders of lipid metabolism in the CNS, to changes in the metabolism of $A \beta$ and to disruption of neuroimmune regulation in the CNS [7].

A significant role in the pathogenesis of AD belongs to the activation of the mechanisms of neuroinflammation, which contributes to neuronal damage and neurodegeneration. There is a hypothesis that chronic infections may play a role in the development and maintenance of the inflammatory response in the early stages of AD. A number of neurotropic infectious agents including herpesviruses have been found in the postmortal brain of AD patients, and there is data in the literature that supports their possible role in the pathogenesis of neuroinflammation in $\mathrm{AD}$ [7]. Even their latent presence can activate microglial cells, which cause oxidative stress, neuroinflammation, and neuronal damage [6].

The association of the HSV1 virus with the progression of $\mathrm{AD}$ and the effect of active HSV infection on the risk of AD has been established several decades ago and has been extensively studied [5]. However, the relationship of other herpesviruses (Epstein-Barr virus (EBV), human herpesvirus 6 (HHV-6), and human herpesvirus 7 (HHV-7)) with the risk and progression of AD is much less studied. There are isolated works on the increased frequency of HHV-6 DNA detection in the postmortem brain of $\mathrm{AD}$ patients [12]. In one of the studies, an increase in the frequency of detection of EBV and HHV-6 in blood leukocytes in AD was shown [3]. At the same time, there are practically no studies reporting the results of quantitative assessment of the level of EBV, HHV-6 and HHV-7 DNA in EOAD and LOAD. Also, the relationship of herpesviruses with the clinical course of $\mathrm{AD}$ and with immunological disorders in $\mathrm{AD}$ has been little studied.

The aim of this work was to study the detection rate and DNA level of herpesviruses, as well as their possible relationship between the level of the key cytokines and clinical parameters in early and late onset AD patients.

\section{Materials and methods}

$30 \mathrm{AD}$ patients (13 men, 17 women, mean age $69 \pm 2$ years) at the stage of moderate dementia and 33 age- and sex-matched healthy volunteers have been enrolled into the study. Early onset AD (up to 65 years) was observed in 15 patients (mean age $61 \pm 1.56$ years), late $\mathrm{AD}$ onset (after 65 years) was also noted in 15 patients (mean age $77 \pm 1.71$ years).

The patients and their relatives were familiarized with the study protocol and signed a voluntary informed consent. Inclusion criteria were as follows: the ability to sign and date the informed consent form or the presence of a legal representative who can sign and date the informed consent form; AD diagnosis according to NINCDS / ADRDA criteria and MMSE score $\leq 26$ points; score on the Khachinski scale $\leq 4$; geriatric depression score $\leq 10$.

DNA of CMV, EBV, HHV-6, HHV-7 were quantified by PCR on a Rotor-Gene Q analyzer (Qiagen, Germany) using the AmpliSens reagent kits (AmpliSens, Moscow). The level of serum cytokines and soluble IL-1 $\beta$ antagonist (IL-1 ra) was determined by ELISA on an iMARK immunoanalyzer (Bio-Rad, USA) using test systems manufactured by "Cytokin", Russia (IFN $\gamma$, IL-4, IL-8, IL-1ra), BCM Diagnostics, USA (IL-12p40p70), and Bender Medsystems, Australia (IL-2).

Herpesvirus infection with escalated viral load was determined, based on our previous data, if at least one of the 2 criteria was present: 1) DNA level of EBV and/or HHV-6 > 10,000 copies/ml in saliva; 2) the presence of DNA of at least one of the EBV, HHV-6, HHV-7 viruses in the blood [4].

The following tests and scoring scales were used for neuropsychological examination: clinical dementia rating scale (CDR); mini-mental state examination (MMSE); frontal assessment battery; clock drawing test; Boston naming test.

Microsoft Excel software was used for statistical analysis. The distribution of the studied parameters was assessed using the Shapiro-Wilks test. The results were presented as means with standard error. While 
comparing differences a significance level was set at $\mathrm{p}<0.05$. Student's $\mathrm{t}$ test was used to compare group means, the Chi-squared test was used to compare relative values.

The authors are grateful to Olga Shipulina, Elvira Domonova and Olga Silveistrova for providing the reagents for HHV-7 detection.

\section{Results and discussion}

It was found that CMV was detected neither in saliva nor blood in any patient. However, EBV and HHV-6 were detected in the patients with a high frequency (Table 1).

The frequency of herpesvirus detection and the viral load depending on the age of $\mathrm{AD}$ onset is presented in Table 1. DNA of at least one of the EBV, HHV-6 and HHV-7 viruses was detected in the blood of 8/15 patients with EOAD, in 4 out of 15 patients with LOAD, and in 3 out of 33 healthy volunteers. Increased viral load was observed in 9 out of 15 patients with EOAD (significantly more often compared with control group, $\mathrm{p}<0.05$ ), 8 out of 15 patients with LOAD, and 6 out of 33 healthy volunteers.

In EOAD, increased viral load was associated with lower Boston naming test scores, which reflects more pronouncedly impaired nominative function of speech $(p=0.016)$ (Figure 1).

Previously, we presented data on the level of the key cytokines in EOAD and LOAD by showing increased level of proinflammatory cytokines IL-8, TNF $\alpha$, and IL-1 ra in patients vs controls [10]. Here, we analyzed the level of cytokines (interferon- $\gamma$ (IFN $\gamma$ ), tumor necrosis factor- $\alpha$ (TNF $\alpha)$, interleukin-4 (IL-4), IL-8, IL-12p40p70, IL-2) and IL-1 ra coupled to viral load in patients with EOAD and LOAD (Table 2). The subgroup of patients with increased viral load and EOAD revealed a significantly higher rise in the levels of certain cytokines: proinflammatory IL-8 and IL-12, a Th2-cytokine IL-4, a cytokine of the adaptive immune response IL-2. At the same time, the level of the anti-inflammatory protein IL-1ra was significantly lower than in the controls. Considering the lack of increased level of the key Th1-cytokine, IFN $\gamma$, these changes may indicate a dysregulated antiviral response, with a predominance of activated systemic inflammation and Th2-mediated reactions.

The role of herpesvirus infections in the pathogenesis of Alzheimer's disease has been long studied, however, most works are devoted to the herpes simplex virus type $1(\mathrm{HHV}-1)$ and refer to patients with late onset $\mathrm{AD}$ as the most common clinical form. In this pilot study, we for the first time assessed the levels of herpesvirus DNA in AD with early and late onset. An increased frequency of detected herpesvirus DNA was found for both EOAD and LOAD, but in the latter EBV was more frequent and at higher levels detected in saliva, whereas in the former the rate of HHV-6 DNA detection was increased in saliva and blood, and the levels of HHV-6 in saliva was increased.

\section{TABLE 1. FREQUENCY OF DETECTION OF DNA OF HERPESVIRUSES IN SALIVA AND BLOOD AND THE LEVEL OF VIRAL LOAD IN EARLY-ONSET ALZHEIMER'S DISEASE (EOAD), LATE-ONSET ALZHEIMER'S DISEASE (LOAD) AND IN THE CONTROL GROUP}

\begin{tabular}{|c|c|c|c|c|}
\hline Disease/viruses & $\begin{array}{l}\text { EBV, frequency } \\
\text { and copy number }\end{array}$ & $\begin{array}{l}\text { HHV-6, frequency } \\
\text { and copy number }\end{array}$ & $\begin{array}{l}\text { HHV-7, frequency } \\
\text { and copy number }\end{array}$ & $\begin{array}{c}\text { CMV, } \\
\text { frequency }\end{array}$ \\
\hline Control group, $n=33$ (saliva) & $\begin{array}{c}6 / 33 \\
6.3 \times 10^{2} \pm 5.6 \times 10^{1} \\
\text { copies } / \mathrm{ml}\end{array}$ & $\begin{array}{c}17 / 33 \\
5.0 \times 10^{2} \pm 3.2 \times 10^{2} \\
\text { copies } / \mathrm{ml}\end{array}$ & $\begin{array}{c}30 / 33 \\
7.6 \times 10^{5} \pm 2.9 \times 10^{5} \\
\text { copies } / \mathrm{ml}\end{array}$ & $0 / 33$ \\
\hline Control group, $n=33$ (blood) & $\begin{array}{c}2 / 33 \\
1.7 \times 10^{1} \pm 1.4 \times 10^{1} \\
\text { copies } / 10^{6} \text { cells }\end{array}$ & $\begin{array}{c}1 / 33 \\
2.6 \times 10^{1} \pm 2.6 \times 10^{1} \\
\text { copies } / 10^{6} \text { cells }\end{array}$ & $\begin{array}{c}3 / 33 \\
6.2 \times 10^{1} \pm 6.2 \times 10^{1} \\
\text { copies } / 10^{6} \text { cells }\end{array}$ & $0 / 33$ \\
\hline EOAD, $n=15$ (saliva) & $\begin{array}{c}8 / 15^{\star} \\
1.6 \times 10^{3} \pm 4.2 \times 10^{2} \\
\text { copies } / \mathrm{ml}\end{array}$ & $\begin{array}{c}15 / 15^{\star} \\
1.1 \times 10^{3} \pm 2.2 \times 10^{2} \\
\text { copies } / \mathrm{ml}\end{array}$ & $\begin{array}{c}14 / 15 \\
5.3 \times 10^{4} \pm 1.1 \times 10^{4} \\
\text { copies } / \mathrm{ml}\end{array}$ & $0 / 15$ \\
\hline EOAD, $n=15$ (blood) & $\begin{array}{c}2 / 15 \\
2.9 \times 10^{1} \pm 2.9 \times 10^{1} \\
\text { copies } / 10^{6} \text { cells }\end{array}$ & $\begin{array}{c}6 / 15^{\star} \\
1.0 \times 10^{2} \pm 1.2 \times 10^{1} \\
\text { copies } / 10^{6} \text { cells }\end{array}$ & $\begin{array}{c}4 / 15 \\
3.9 \times 10^{3} \pm 1.2 \times 10^{3} \\
\text { copies } / 10^{6} \text { cells }\end{array}$ & $0 / 15$ \\
\hline LOAD, n = 15 (saliva) & $\begin{array}{c}10 / 15^{*} \\
5.2 \times 10^{5} \pm 3.1 \times 10^{5^{*}} \\
\text { copies } / \mathrm{ml}\end{array}$ & $\begin{array}{c}10 / 15 \\
3.8 \times 10^{3} \pm 1.5 \times 10^{3} \\
\text { copies } / \mathrm{ml}\end{array}$ & $\begin{array}{c}12 / 15 \\
3.9 \times 10^{4} \pm 2.9 \times 10^{4} \\
\text { copies } / \mathrm{ml}\end{array}$ & $0 / 15$ \\
\hline LOAD, n = 15 (blood) & $\begin{array}{c}2 / 15 \\
4.2 \times 10^{2} \pm 4.2 \times 10^{2} \\
\text { copies } / 10^{6} \text { cells }\end{array}$ & $\begin{array}{c}2 / 15 \\
4.5 \times 10^{1} \pm 4.5 \times 10^{1} \\
\text { copies } / 10^{6} \text { cells }\end{array}$ & $0 / 15$ & $0 / 15$ \\
\hline
\end{tabular}

Note. ${ }^{*}$, significant differences with the control group, $\mathrm{p}<0.05$. 


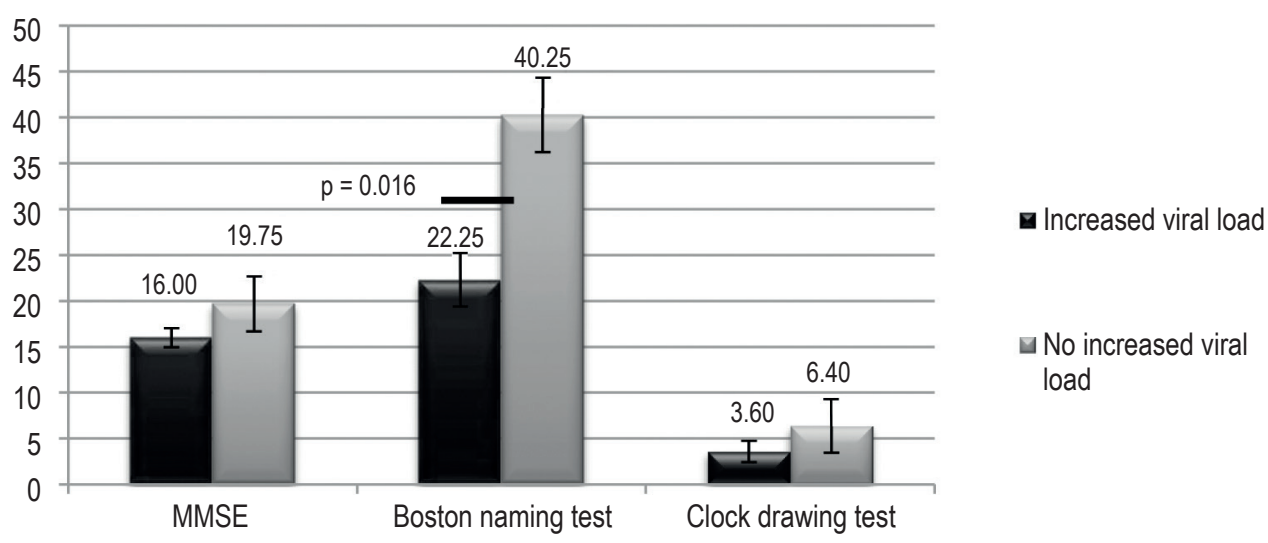

Figure 1. Results of neuropsychological examination in early-onset Alzheimer's disease in patients with and without an increased viral load (the DNA level of EBV and/or HHV-6 viruses is more than 10000 copies/ml in saliva; or the presence of DNA at least one of EBV, HHV-6, HHV-7 viruses in the blood)

Note. Lower values indicate more pronounced neuropsychological deficits

The relationship between viral load with declined cognitive functions and immunological parameters was found in patients with early onset $\mathrm{AD}$, but not in late onset $\mathrm{AD}$, which might be due to the phenotypic patient heterogeneity [8]. According to the data obtained, the increased viral load in EOAD is associated with activated low-grade systemic inflammation and the Th2-arm of the immune response. According to the literature, such changes may be related to the development and progression of neurodegeneration. Thus, CNS macrophages and microglial cells acquire the M2 phenotype, disrupting the mechanisms of effective antiviral defense affected by the Th2-cytokine IL-4 [13]. Pro-inflammatory IL-8, TNF $\alpha$, IL-12 stimulate macrophage activation, production of chemokines and other inflammatory factors. According to our results, the pre-dementia
AD stage and amnestic mild cognitive impairment (aMCI) were coupled to increased levels of IL-1 $\beta$, TNF $\alpha$ and IL-8, which correlated with a higher probability of progression to AD [8]. IL-12 is a potent stimulator of IFN $\gamma$ production activating the Th1-arm of adaptive immunity; however, an impaired regulation of the immune response may be bound to dominance of its pro-inflammatory effect. The knockout of the p40 subunit of IL-12, IL-23 dimeric cytokine slows aging-associated neuronal loss and $A \beta$ deposition in wild-type mice [15].

The presence of chronic systemic inflammation increases the risk of AD by 1.5-1.8 times [14]. It is also known that $A \beta$ is an antimicrobial protein and an important element of the innate immune defense system. There is evidence that the reactivation of latent infections increases $\mathrm{A} \beta$ production, which contributes

TABLE 2. THE VIRAL LOAD AND THE LEVELS OF THE MAIN CYTOKINES IN THE BLOOD IN EARLY ONSET ALZHEIMER'S DISEASE (EOAD), LATE ONSET ALZHEIMER'S DISEASE (LOAD) AND IN THE CONTROL GROUP

\begin{tabular}{|c|c|c|c|c|c|}
\hline & & & LO & & \\
\hline & $\begin{array}{c}\text { Increased viral } \\
\text { load }\end{array}$ & $\begin{array}{l}\text { No increased } \\
\text { viral load }\end{array}$ & $\begin{array}{c}\text { Increased viral } \\
\text { load }\end{array}$ & $\begin{array}{l}\text { No increased } \\
\text { viral load }\end{array}$ & Controls \\
\hline MMSE & $16.0 \pm 2.1$ & $19.7 \pm 6.0$ & $20.8 \pm 1.8$ & $16.7 \pm 4.6$ & $30.0 \pm 0.0$ \\
\hline Boston naming test & $22.3 \pm 5.6^{*}$ & $40.2 \pm 7.9$ & $34.0 \pm 11.2$ & $30.5 \pm 0.8$ & $52.2 \pm 2.2$ \\
\hline IFN $\gamma, \mathrm{pg} / \mathrm{ml}$ & $295.5 \pm 63.6$ & $234.7 \pm 48.7$ & $225.1 \pm 52.6$ & $150.7 \pm 20.6$ & $232.5 \pm 6.4$ \\
\hline TNF $\alpha, p g / m l$ & $6.2 \pm 0.8$ & $9.4 \pm 2.0$ & $4.7 \pm 0.6$ & $5.5 \pm 0.1$ & $3.2 \pm 0.3$ \\
\hline IL-2, pg/ml & $295.8 \pm 179.1$ & $27.9 \pm 14.1$ & $12.5 \pm 0.9$ & $12.5 \pm 0.4$ & $13.7 \pm 1.1$ \\
\hline IL-4, pg/ml & $16.3 \pm 8.5$ & $0.02 \pm 0.02$ & $0.3 \pm 0.3$ & $2.8 \pm 1.0$ & $1.42 \pm 0.53$ \\
\hline IL-8, pg/ml & $190.8 \pm 90.1$ & $60.0 \pm 19.2$ & $40.7 \pm 17.3$ & $18.3 \pm 5.5$ & $15.97 \pm 2.00$ \\
\hline IL-12p40p70, pg/ml & $196.6 \pm 27.7$ & $134.5 \pm 25.2$ & $186.1 \pm 45.0$ & $202.1 \pm 41.5$ & $142.7 \pm 16.81$ \\
\hline IL-1ra, pg/ml & $30.8 \pm 16.3$ & $845.1 \pm 706.1$ & $78.5 \pm 55.6$ & $935.4 \pm 441.7$ & $133.1 \pm 40.3$ \\
\hline
\end{tabular}

Note. * , significant differences between groups, $\mathrm{p}<0.05$; bold, significant differences with the control group, $\mathrm{p}<0.05$. 
to developing neuroinflammation, and subsequent formation of senile plaques [2]. It cannot be ruled out that impaired immunity and systemic inflammation, observed upon increased EBV and HHV-6 viral load in patients with early onset $\mathrm{AD}$, affect neurodegeneration, modulating the activity of neuroinflammation mechanisms through neuroimmune interactions. It is important to note that early onset AD patients with increased viral load had lower Boston naming test score, suggesting more pronouncedly impaired nominative function of speech. Taking into account our previous results and literature data, emphasizing that systemic inflammation and disorders of adaptive immunity are a risk factor for the $\mathrm{AD}$ progression, the results obtained indicate a possible pathogenetic role of immunological disorders associated with high viral load in early onset AD.

We have previously described immunological disorders at different stages of $\mathrm{AD}$, as well as immunological heterogeneity of $\mathrm{AD}$ at its pre-dementia stage (aMCI), showing that the type and severity of immunological disorders are associated with the risk of $\mathrm{AD}$ progression $[2,9]$. According to the results of our pilot study, the relationship of infectious factors between immunological parameters and clinical characteristics in $\mathrm{AD}$ is uneven depending on the age of disease onset. It is known that early onset $A D$ and late onset $\mathrm{AD}$ differ in genetic predisposition factors, which may affect differences in pathogenetic mechanisms. It is possible that in early onset $\mathrm{AD}$, an increase in the viral load upon reactivation of chronic viral infections and the immunological disorders associated with related reactivation may contribute to neuroinflammation and more rapid progression of neurodegeneration. Further research is needed to investigate a role of infectious factors in developing Alzheimer's disease. The presented results indicate that in the studies of AD mechanisms and in the search for prognostic disease markers, it is important to take into account the heterogeneity of AD in terms of genetic predisposition factors, risk factors, immune parameters and clinical data. Such an approach is necessary for subsequent development of personalized approaches for $\mathrm{AD}$ prevention and treatment.

\section{References}

1. Alzheimer's Association. 2017 Alzheimer's disease facts and figures. Alzheimer Dement., 2017, Vol. 13, no. 4, pp. 325-373.

2. Bourgade K., le Page A., Bocti C., Witkowski J.M., Dupuis G., Frost E.H., Tamásf F.J. Protective Effect of Amyloid- $\beta$ Peptides Against Herpes Simplex Virus-1 Infection in a Neuronal Cell Culture Model. J. Alzheimers Dis., 2016, Vol. 50, no. 4, pp. 1227-1241.

3. Carbone I., Lazzarotto T., Ianni M., Porcellini E., Forti P., Masliah E., Gabrielli L., Licastro F. Herpes virus in Alzheimer's disease: relation to progression of the disease. Neurobiol. Aging, 2014, Vol. 35, no. 1, pp. 122-129.

4. Didkovsky N.A., Ogurtsov D.P., Krynskiy S.A., Gurskaya O.G., Shipulina O.Y., Domonova E.A., Silveistrova O.Y., Kompaneets I.A., Zharova M., Hailov N.A., Kazanova G.V., Malashenkova I.K. Myalgic encephalomyelitis / chronic fatigue syndrome: replication levels of lymphotropic herpesviruses and immune defense. Polyclinic, 2016, Vol. 5, no. 1, pp. 46-50. (In Russ.)

5. Honjo K., van Reekum R., Verhoeff N. Alzheimer's disease and infection: Do infectious agents contribute to progression of Alzheimer's disease? Alzheimers Dement., 2009, Vol. 5, no. 4, pp. 348-360.

6. Kuhla A., Ludwig S.C., Kuhla B., Münchc G., Vollmara B. Advanced glycation end products are mitogenic signals and trigger cell cycle reentry of neurons in Alzheimer's disease brain. Neurobiol. Aging, 2015, Vol. 36, no. 2, pp. 753-761.

7. Malashenkova I.K., Krynskiy S.A., Mamoshina M.V., Didkovskiy N.A. APOE gene polymorphism: the impact of ApoE4 allele on systemic inflammation and its role in the pathogenesis of Alzheimer's disease. Medical Immunology (Russia), 2018, Vol. 20, no. 3, pp. 301-310. (Russ.)] doi: 10.15789/1563-0625-2018-3-303-312.

8. Malashenkova I.K., Krynskiy S.A., Khailov N.A., Ogurtsov D.P., Chekulaeva E.I., Ponomareva E.V., Gavrilova S.I., Didkovsky N.A. Immunological variants of amnestic mild cognitive impairment. S. Korsakov Journal of Neurology and Psychiatry, 2020, Vol. 120, no. 10, pp. 60-68. (In Russ.)]

9. Malashenkova I.K., Krynskiy S.A., Khailov N.A., Ogurtsov D.P., Ponomareva E.V., Gavrilova S.I., Didkovsky N.A. Adaptive immunity, systemic inflammation and cytokine levels in patients with Alzheimer's disease of different severity and with amnestic mild cognitive impairment. Allergologiya $i$ immunologiya $=$ Allergology and Immunology, 2018, Vol. 19, no. 4, pp. 206-214. (In Russ.)]

10. Malashenkova I.K., Hailov N.A., Krynskiy S.A., Ogurtsov D.P., Kazanova G.V., Velichkovskiy B.B., Selesneva N.D., Fedorova Y.B., Ponomareva E.V., Kolyhalov I.V., Gavrilova S.I., Didkovsky N.A.. Levels of proinflammatory cytokines and growth factor VEGF in patients with Alzheimer's disease and mild cognitive impairment. Neurosci. Behav. Physiol., 2017, Vol. 47, no. 6, pp. 694-698.

11. Meraz-Ríos M.A., Franco-Bocanegra D., Toral Rios D., Campos-Peña V. Early onset Alzheimer’s disease and oxidative stress. Oxid. Med. Cell. Longev., 2014, Vol. 2014, 375968. doi: 10.1155/2014/375968. 
12. Ortega-Madueño I., Garcia-Montojo M., Dominguez-Mozo M.I., Garcia-Martinez A., Arias-Leal A.M., Casanova I., Arroyo R., Alvarez-Lafuente R. Anti-human herpesvirus 6A/B IgG correlates with relapses and progression in multiple sclerosis. PLoS One, 2014, Vol. 9, no. 8, e104836. doi: 10.1371/journal.pone.0104836.

13. Szczepanik A.M., Funes S., Petko W., Ringheim G. IL-4, IL-10 and IL-13 modulate A beta (1-42)-induced cytokine and chemokine production in primary murine microglia and a human monocyte cell line. J. Neuroimmunol., 2001, Vol. 113, no. 1, pp. 49-62.

14. Takeda S., Sato N., Morishita R. Systemic inflammation, blood-brain barrier vulnerability and cognitive/ non-cognitive symptoms in Alzheimer disease: relevance to pathogenesis and therapy. Front. Aging Neurosci., 2014, Vol. 6, 171. doi: 10.3389/fnagi.2014.00171.

15. Tan M.S., Yu J.T., Jiang T., Zhu X.C., Guan H.S., Tan L. IL12/23 p40 inhibition ameliorates Alzheimer's disease-associated neuropathology and spatial memory in SAMP8 mice. J. Alzheimers Dis., 2014, Vol. 38, no. 3, pp. 633-646.

16. Zou Z., Liu C., Che C., Huang H. Clinical genetics of Alzheimer's disease. Biomed Res. Int., 2014, Vol. 2014, 291862. doi: 10.1155/2014/291862.

\section{Авторы:}

Малашенкова И.К. - к.м.н., начальник лаборатории молекулярной иммунологии и вирусологии, Национальный исследовательский центр «Курчатовский институт»; ведущий научный сотрудник лаборатория клинической иммунологии ФГБУ «Федеральный научно-клинический центр физико-химической медицины ФМБА России», Москва, Россия

Огурцов Д.П. - к.м.н., научный сотрудник лаборатории молекулярной иммунологии и вирусологии, Национальный исследовательский центр «Курчатовский институт»; научный сотрудник лаборатория клинической иммунологии ФГБУ «Федеральный научно-клинический центр физикохимической медицины ФМБА России», Москва, Россия

Крынский С.А. - к.м.н., научный сотрудник лаборатории молекулярной иммунологии и вирусологии, Национальный исследовательский центр «Курчатовский институт», Москва, Россия

\section{Authors:}

Malashenkova I.K., PhD (Medicine), Head, Laboratory of Molecular Immunology and Virology, National Research Center "Kurchatov Institute"; Leading Research Associate, Laboratory of Clinical Immunology, Federal Research and Clinical Center of Physical-Chemical Medicine, Federal Medical-Biological Agency of Russia, Moscow, Russian Federation

Ogurtsov D.P., PhD (Medicine), Research Associate at Laboratory of Molecular Immunology and Virology, National Research Center "Kurchatov Institute"; Research Associate, Laboratory of Clinical Immunology, Federal Research and Clinical Center of Physical-Chemical Medicine, Federal Medical-Biological Agency of Russia, Moscow, Russian Federation

Krynskiy S.A., PhD (Medicine), Research Associate, Laboratory of Molecular Immunology and Virology, National Research Center "Kurchatov Institute", Moscow, Russian Federation 
Крынский С.А. - к.м.н., научный сотрудник лаборатории молекулярной иммунологии и вирусологии, Национальный исследовательский центр «Курчатовский институт», Москва, Россия

Хайлов Н.А. - к.м.н., старший научный сотрудник ресурсного центра молекулярной и клеточной биологии, Национальный исследовательский центр «Курчатовский институт», Москва, Россия

Селезнева Н.Д. - д.м.н., профессор, ведущий научный сотрудник отдела гериатрической психиатрии ФГБНУ «Научный центр психического здоровья», Москва, Россия

Федорова Я.Б. - к.м.н., старший научный сотрудник отдела гериатрической психиатрии ФГБНУ «Научный центр психического здоровья», Москва, Россия

Пономарева Е.В. - к.м.н., старший научный сотрудник отдела гериатрической психиатрии ФГБНУ «Научный центр психического здоровья», Москва, Россия

Колыхалов И.В. - д.м.н., главный научный сотрудник отдела гериатрической психиатрии ФГБНУ «Научный иентр психического здоровья», Москва, Россия

Гаврилова С.И. - д.м.н., профессор, заведующая отделом гериатрической психиатрии ФГБНУ «Научный центр психического здоровья», Москва, Россия

Дидковский Н.А. - д.м.н., профессор, заведующий лабораторией клинической иммунологии ФГБУ «Федеральный научно-клинический центр физикохимической медицины ФМБА России», Москва, Россия
Krynskiy S.A., PhD (Medicine), Research Associate, Laboratory of Molecular Immunology and Virology, National Research Center "Kurchatov Institute”, Moscow, Russian Federation

Khailov N.A., PhD (Medicine), Senior Research Associate, Resource Center for Molecular and Cellular Biology, National Research Center "Kurchatov Institute", Moscow, Russian Federation

Selezneva N.D., PhD, MD (Medicine), Professor, Leading Research Associate, Department of Geriatric Psychiatry, Mental Health Research Center, Moscow, Russian Federation

Fedorova Ya.B., PhD (Medicine), Senior Research Associate, Department of Geriatric Psychiatry, Mental Health Research Center, Moscow, Russian Federation

Ponomareva E.V., PhD (Medicine), Senior Research Associate, Department of Geriatric Psychiatry, Mental Health Research Center, Moscow, Russian Federation

Kolykhalov I.V., PhD, MD (Medicine), Chief Research Associate, Department of Geriatric Psychiatry, Mental Health Research Center, Moscow, Russian Federation

Gavrilova S.I., PhD, MD (Medicine), Professor, Head, Department of Geriatric Psychiatry, Mental Health Research Center, Moscow, Russian Federation

Didkovsky N.A., PhD, MD (Medicine), Professor, Head, Laboratory of Clinical Immunology, Federal Research and Clinical Center of Physical-Chemical Medicine, Federal Medical-Biological Agency of Russia, Moscow, Russian Federation

Поступила 15.12.2020

Принята к печати 11.05.2021

Received 15.12.2020

Accepted 11.05.2021 